Preliminary communication

https://doi.org/10.32903/zs.66.1.5

UDK 004:371.3-057.87

\title{
SOCIAL NETWORKS FOR BETTER EDUCATION AND BETTER GRADES
}

\author{
Alta Pavin Banović, mag. theol., mag. bibl. \\ Medical School Osijek \\ Sanja Dravinski, mag. med. techn. \\ Medical School Osijek
}

\begin{abstract}
The goal of the paper is to show the results of a research conducted among students of Medical School Osijek on the use of social media as tools for exchanging educational content with their teachers, which leads to a better adoption of the content and better grades. Teachers and students learn about social media through preventive programs. The research method is an online survey conducted in 10 class departments. Results: Modern social media used in teaching enable better communication between students and teachers, faster information flow and easier preparation of students for school as well as development of a positive attitude on the use of social media in the teaching process.
\end{abstract}

Keywords: communication, teaching for media, high school students, learning, social media

\section{INTRODUCTION}

Thanks to the development, availability and the use of information and communication technologies at the beginning of the $21^{\text {st }}$ century, humankind has entered into a new era, information era, characterized as an era of skills, society of knowledge or information. Since the Internet has branched out into all areas of human society, the possibility of obtaining the necessary information is open at any time. "The Internet is a set of computer networks connected so that data can be sent and messages converted... and millions of users from all over the world are connected to it." (Anić and Goldstein, 2000: 612; Anić, 2003: 450). The Internet is used to find the necessary information, send specific messages and to communicate.

The reason for the communication is the information which, according to the Rječnik stranih riječi by Anić and Goldstein $(2000,597)$, is the result of processing, manipulating and organizing data. A message is a materialized form of the information. The primary feature of a message is that the information is informative because it provides the recipient with new information which can be false or true (Anić, 2003, 441). Information is transmitted by signs or letters (Anić, 2003) that involve the relationship between a person and an object. Conventional signs are agreed upon. They are used in various ways to get the desired reaction of the recipient.

Communication is a process, transmission of certain information or message... most often through language (Anić and Goldstein, 2000, 713; Anić, 2003, 599), and language is a communication system composed of signs and rules (Anić, 1991, 243; Anić, 2003, 526). In the means of social communication we use different forms of verbal and non-verbal speech, such as: facial expressions, hand movements, body position, spoken and written words in the mass media. Word communication literally means: to share, to make something general or common 
and is described according to content, form and purpose. The content and form of the communication create messages that are sent to a certain target, which is another person, organization or society. The form of communication is not only through text, but also images in the form of photos and videos. Video is a term for the technical process of recording, copying, processing, transmission and display of moving images that can be viewed on the screen. Communication between people certainly requires understanding, response or reaction, agreement or feed-back (Blažević, Cividini-Stranić and Beck-Dvoržak, 1978). Most often, communication takes place in a group or community. It starts at a primitive, inarticulate level and gradually reaches the degree of conventionally transmitted verbal and verbal emotional information (Blažević et al., 1978). A human is a social being and the communication and encounters with people are inscribed in his nature, which leave a deep mark in his formation (Blažević et al., 1978).

The society today imposes on individuals various forms of communication. A widespread form of communication are social networks, online services that we use to arrange meetings, share text contents, photos, documents, links, videos and similar content.

\section{Methodology}

In December 2019 and January 2020, Osijek Medical School conducted an online research on the topic of social networks for better teaching and better grades. The questions posed in the research were simple and understandable, and the scalar methods for measuring attitudes were used: Thurston's scale consisting of statements with which the student may or may not agree and Likert's scale consisting of a series of statements with which students indicate the degree of acceptability (numbers from 1 to 5 ). The attitude is scaled by the sum of numerical values. A descriptive assessment scale that consists of a single choice from a number of claims was also used. Examinee selects a choice that, in his opinion, is the most true. To obtain a mean average, an odd number of claims was used.

Respondents completed the questionnaire on their smartphones and personal computers in the school library or at home using the link http://bit.ly/dm2020nastava. 227 students participated in the survey, 134 first-year students and 94 last-year students. A total of 43 male and 184 female students participated.

\section{THE RESULTS OF RESEARCH AND INTERPRETATION}

The results of the analysis of the answers collected with the research Social networks for better teaching and better grades, showed that $97.35 \%(\mathrm{~N}-221)$ students use social networks daily. Only $2.64 \%$ (N-6) surveyed students do not use them on a daily basis.

The level of parents' awareness of the content that their children, high school students, post on social networks is shown by the fact that $46.69 \%$ of parents $(\mathrm{N}-106)$ read the posts of their children, and $53.30 \%(\mathrm{~N}-121)$ of parents do not know what content their children post.

A very small percentage of parents, $7.48 \%(\mathrm{~N}-17)$, limit their children's time spent on social media and the Internet in general, and $92.51 \%(\mathrm{~N}-210)$ of parents do not limit their children's time on social media.

As parents, teachers as well, in a small percentage, $7.48 \%(\mathrm{~N}-17)$, follow students' posts on social networks. Similarly, a small percent of the students, $18.50 \%(\mathrm{~N}-42)$, follow posts of their teachers on social networks, and $81.49 \%(\mathrm{~N}-185)$ of the students do not follow their teachers' posts on social networks. 
These results show that the opportunities provided by social networks are insufficiently recognized and used for better communication and better connection between students and teachers and the mutual exchange of teaching content.

A similar survey on the use of the Internet was conducted by Plavi telefon and the Child Protection Polyclinic of the City of Zagreb, which can be compared with the results of a study conducted at the Osijek Medical School. The surveyed persons in this survey were between 11 and 18 years of age, while the surveyed students of the Medical School Osijek were between 15 and 19 years of age. The results of the analysis of this questionnaire show that $95 \%$ of respondents use the Internet and that $49 \%$ of children use the Internet without the supervision and presence of adults. With $46 \%$ of children, parents are sometimes present, and with $2.5 \%$ of children, one of the parents is present. Slightly more than a third, $36 \%$ of children, stated that parents are not interested in the content they search and use on the Internet (Mandarić, 2012). These results are an indication that parents, as well as teachers, do not recognize the positive possibilities of the Internet that can improve communication between teachers and students, class teachers and parents, extracurricular cooperation and teacher learning.

Research at the Medical School Osijek showed that the most frequently used social networks in communication with friends are Instagram - 78.41\% (N-178), Facebook $-41.4 \%$ (N-94), Snapchat 36.56\% (N-83), WhatsApp 31.52\% (N-72). Social networks that are used in a very small percentage are: TikTok $-5.72 \%(\mathrm{~N}-13)$, Twitter $-0.8 \%(\mathrm{~N}-2)$, and Other $-5.72 \%(\mathrm{~N}-$ 13). In general, they do not use LinkedIn $-0 \%$.

\begin{tabular}{lc} 
Facebook & 94 \\
Whatsapp & 72 \\
Instagram & 178 \\
Snapchat & 83 \\
Tinkedin & 2 \\
TikTok & 0 \\
\hline
\end{tabular}

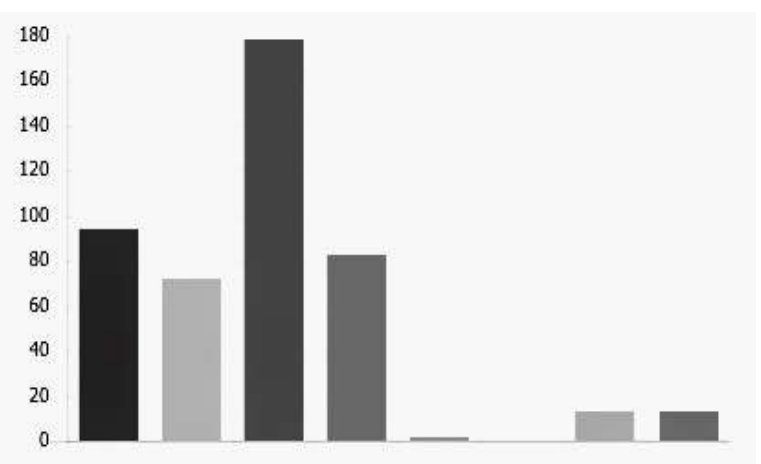

Figure 1. The use of social networks to communicate with friends

These results can be compared with the results of the questionnaire by the author Siniša Kušić, published in the journal Life and School 2010, in article Online social networks and social networking in elementary school: habits of the facebook generation. This research has shown that " $63.4 \%$ of students use MSN for online communication with friends, $14.6 \%$ of them use Skype, and $29.3 \%$ of students use another online social network or tool to communicate with friends" (Kušić, 2010: 120).

The most commonly used means of communication between teachers and students are: e-mail 30.39\% (N-69), Viber - 12.33\% (N-28) and Messenger - 6.16\% (N-14) while 1.32\% (N-3) students do not communicate with teachers online. The most represented social networks are: Facebook 45.37\% (N-103), WhatsApp 12.33\% (N-28), Instagram 1.76\% (N-4) and Twitter 0.44\% (N-1). Social networks Snapchat, LinkedIn and TikTok are not at options for mutual communication and sharing educational materials. Albait $51.10 \%(\mathrm{~N}-116)$ of students has selected that in communication with teachers, they use "Other social networks". 
THEORETICAL AND PRACTICAL PROBLEMS AND DISCUSSIONS

$\begin{array}{ll}\text { Facebook } & 103 \\ \text { WhatsApp } & 28 \\ \text { Instagram } & 4 \\ \text { Snapchat } & 0 \\ \text { Twitter } & 1 \\ \text { Linkedin } & 0 \\ \text { TikTok } & 0 \\ \text { Ostalo } & 116\end{array}$

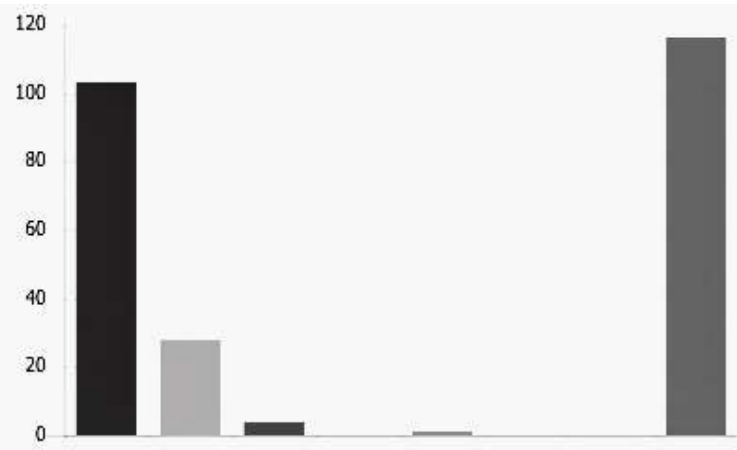

Figure 2. Use of social networks in communication with teachers

The best social networks for communication, according to students, are: Instagram $69.60 \%$ (N-158), YouTube 15.41\% (N-35), Snapchat 3.96\% (N-9), Facebook 3.08\% (N-7), TikTok $2.20 \%(\mathrm{~N}-5)$ and Other $2.20 \%(\mathrm{~N}-5)$. Twitter is not an option for online communication and $3.52 \%(\mathrm{~N}-8)$ of students have not opted for the best social network.

Facebook
Instagram
YouTube
Twitter
TikTok
ne znam
Ostalo

$\begin{array}{ll}7 & 1 \\ 158 & 1 \\ 35 & 120 \\ 9 & 1 \\ 0 & \\ 5 & \\ 5 & \end{array}$

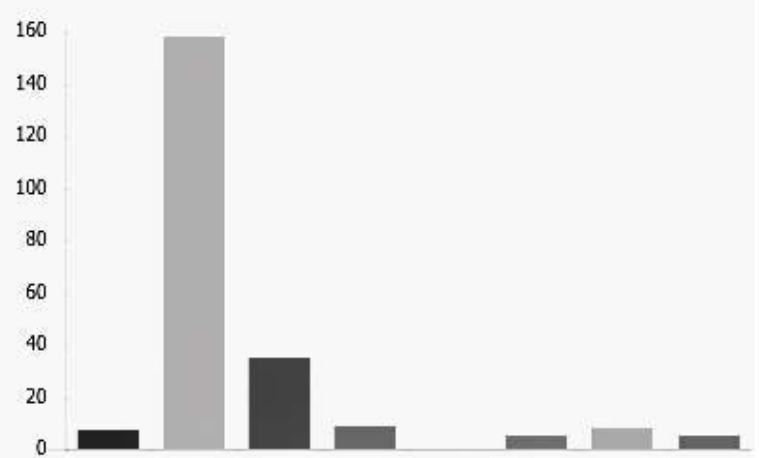

Figure 3. The best social networks for students

Evaluating the quality of published content useful for teaching on social networks, the students rated the best content on YouTube $-35.2 \%$ and Instagram $-22.5 \%$, and the worst they rated the content on TikTok $-59.9 \%$ and Twitter $-48.9 \%$. Other social networks that they use to publish and share their educational content they rated in a small percentage as excellent and in a higher percentage as poor:

YouTube: bad $5.7 \%$, sufficient $6.6 \%, 17.2 \%$ good, very good $35.2 \%$, excellent $35.2 \%$ Instagram: bad $22 \%$, sufficient $13.7 \%$, good $22.5 \%$, very good $19.4 \%$, excellent $22.5 \%$

SnapChat: bad $50.2 \%$, sufficient $15.4 \%$, good $15 \%$, very good $11 \%$, excellent $8.4 \%$

Twitter: poor $48.9 \%$, sufficient $23.8 \%$, good $17.6 \%$, very good $8.4 \%$, excellent $1.3 \%$

TickTok: poor $59,9 \%$, sufficient $13.2 \%$, good $15 \%$, very good $6.2 \%$, excellent $5.7 \%$

Facebook: bad $23.3 \%$, sufficient $25.6 \%$, good $35.2 \%$, very good $12,8 \%$, excellent $3.1 \%$ 


Eloše
Facebook
Instagram
SnapChat
Twitter
YouTube
TikTok

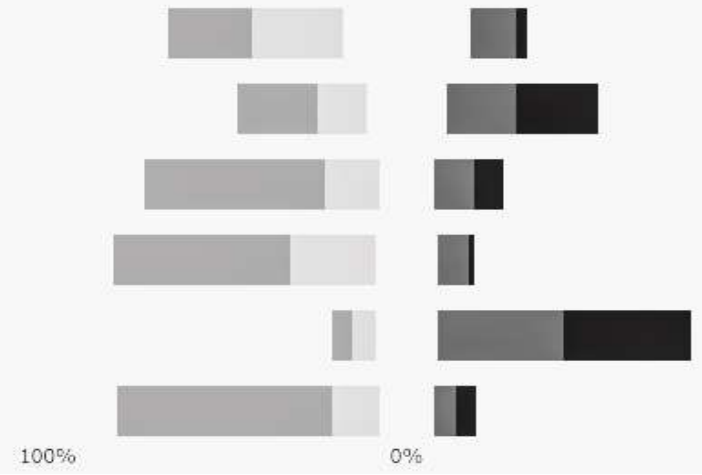

Figure 4. Quality teaching content on social networks

Analysing the already mentioned survey by Siniša Kušić (2010), we can see that 9.6\% of students use Facebook to learn and master the teaching material while $4.9 \%$ of them use the Facebook for some other activities such as: informing about news and creating various groups and participation in them. Of the other social networks, $23.2 \%$ of students use MySpace, $15.9 \%$ use Twitter and 7.3\% of them use Croatian social network Trosjed (Kušić, 2010).

Ten years have passed from 2010 to 2020 and we can conclude that some social networks have disappeared during these ten years and some others have emerged.

Students often post content on social networks in the form of photos $13.2 \%$ and text $3.5 \%$. Largely they do not publish links $-64.8 \%$ and video $-44.5 \%$.

The scale of published content according to the frequency of publication:

Text: never $30 \%$, sometimes $51.1 \%$, often $15.4 \%$, always $3.5 \%$

Photo: never $8.8 \%$, sometimes $51.5 \%$, often $26.4 \%$, always $13.2 \%$

Stickers: never $47.1 \%$, sometimes $36.1 \%$, often $13.7 \%$, always $3.1 \%$

Video: never $44.5 \%$, sometimes $48.5 \%$, often $6.2 \%$, always $0.9 \%$

Links: never $64.8 \%$, sometimes $30 \%$, often $4.4 \%$, always $0.9 \%$

Something else: never $60.4 \%$, sometimes $32.6 \%$, often $6.2 \%$, always $0.9 \%$
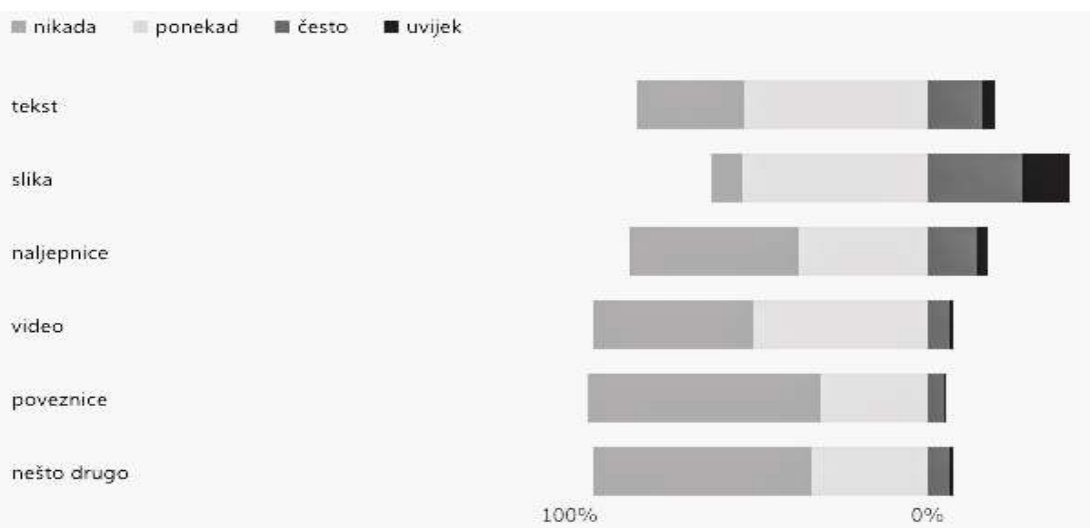

Figure 5. Publishing content on social networks 
THEORETICAL AND PRACTICAL PROBLEMS AND DISCUSSIONS

Students publish content on social networks to preserve memories $-45.8 \%$, for better quality communication $-18.9 \%$, for making friends $-18.5 \%$. Only $15.9 \%$ of students publish content to faster solve their homework.

Posting content on social networks according to the ranking scale:

To store memories: never $2.6 \%$, sometimes $13.7 \%$, often $37.9 \%$, always $45.8 \%$

To better communicate: never $5.3 \%$, sometimes $40.5 \%$, often $35.2 \%$, always $18.9 \%$ making

To make friends: never $2.6 \%$, sometimes $32.6 \%$, often $46.3 \%$, always $18.5 \%$

To do homework faster: never $8.4 \%$, sometimes $36.6 \%$, often $39.2 \%$, always $15.9 \%$

To be better informed: never $4 \%$, sometimes $39.2 \%$, often $44.9 \%$, always $11.9 \%$

Because the teachers are available: never $11.9 \%$, sometimes $49.8 \%$, often $32.2 \%$, always $6.2 \%$

For better grades: never $20.7 \%$, sometimes $51.5 \%$, often $22.9 \%$, always $4.8 \%$

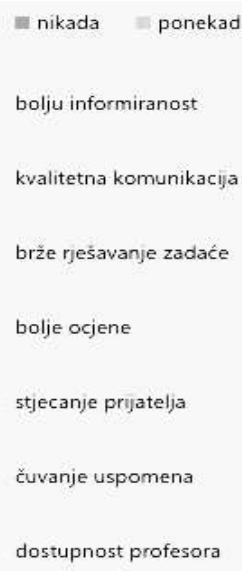

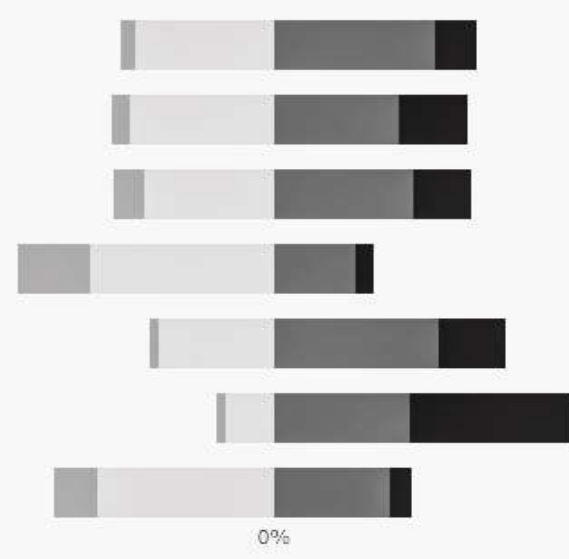

$100 \%$

Figure 6. Content published on social networks

The largest percentage of students share posts on social networks several times a year $31.27 \%(\mathrm{~N}-71)$, several times a month $19.82 \%(\mathrm{~N}-45)$, once a month $18.06 \%(\mathrm{~N}-41)$, once a week $10.13 \%(\mathrm{~N}-23)$, two to three times a week $9.69 \%(\mathrm{~N}-22)$, daily $7.92 \%(\mathrm{~N}-18)$. Almost $10 \%$ of students never share content, and $5.28 \%(\mathrm{~N}-12)$ of students do not know if they share content. "Other" is selected by $0.44 \%(\mathrm{~N}-1)$, e.g. only one student. 
svakodnevno

dva do tri puta tjedno

tjedno

par putã mjesečno

jednom mjesečno

par puta godišnje

nikada

ne znam

Ostalo

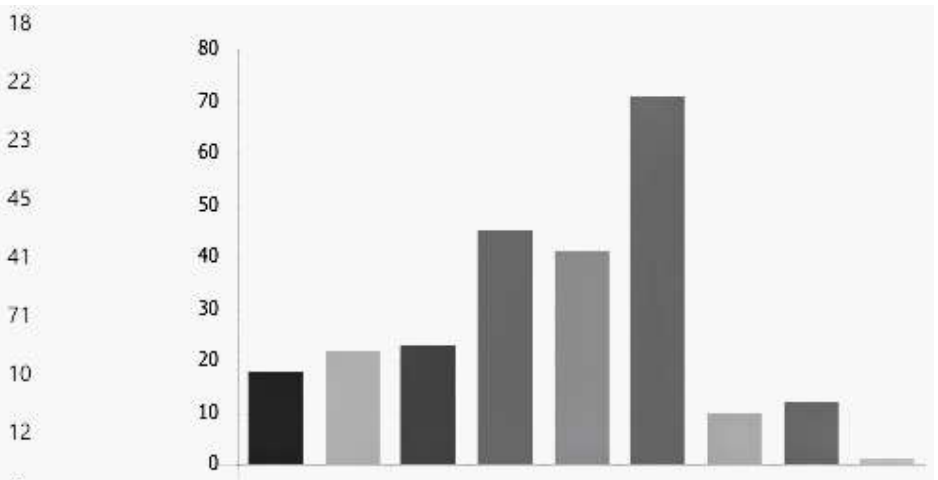

Figure 7. Frequency of sharing content on social networks

Of the total number of surveyed students, $48.01 \%$ (N-109) of them never on social networks share content that can be used for teaching and learning. A total of $24.66 \%(\mathrm{~N}-56)$ of students do not know whether they share teaching content using social networks. $10,13 \%$ of students $(\mathrm{N}-16)$ share contents several times a year, $0.88 \%(\mathrm{~N}-2)$ of students daily, two to three times per week $-3.08 \%(\mathrm{~N}-7)$ students, weekly $-5.72 \%(\mathrm{~N}-13)$ of students, several times a month $-7.04 \%(\mathrm{~N}-16)$ and $2.64 \%(\mathrm{~N}-16)$ of students once a month.

svakodnevno
dva do tri puta tjedno
tjedno
par puta mjesećno
par puta godišnje
nikada
ne znam
Ostalo

Figure 8. Sharing teaching content on social networks

How often do students receive posts on social networks useful for teaching and learning: daily - $11.01 \%(\mathrm{~N}-22)$, two to three times a week - $13.21 \%(\mathrm{~N}-30)$, weekly - $13.21 \%(\mathrm{~N}-30)$, several times a month $-12.77 \%(\mathrm{~N}-29)$, once a month $-6.16 \%(\mathrm{~N}-14)$, several times a year $10.57 \%(\mathrm{~N}-24)$, never - $14.53 \%(\mathrm{~N}-33)$, do not know $20.70 \%(\mathrm{~N}-47)$, and "Other" selected $0.44 \%$ (N-1) students. 


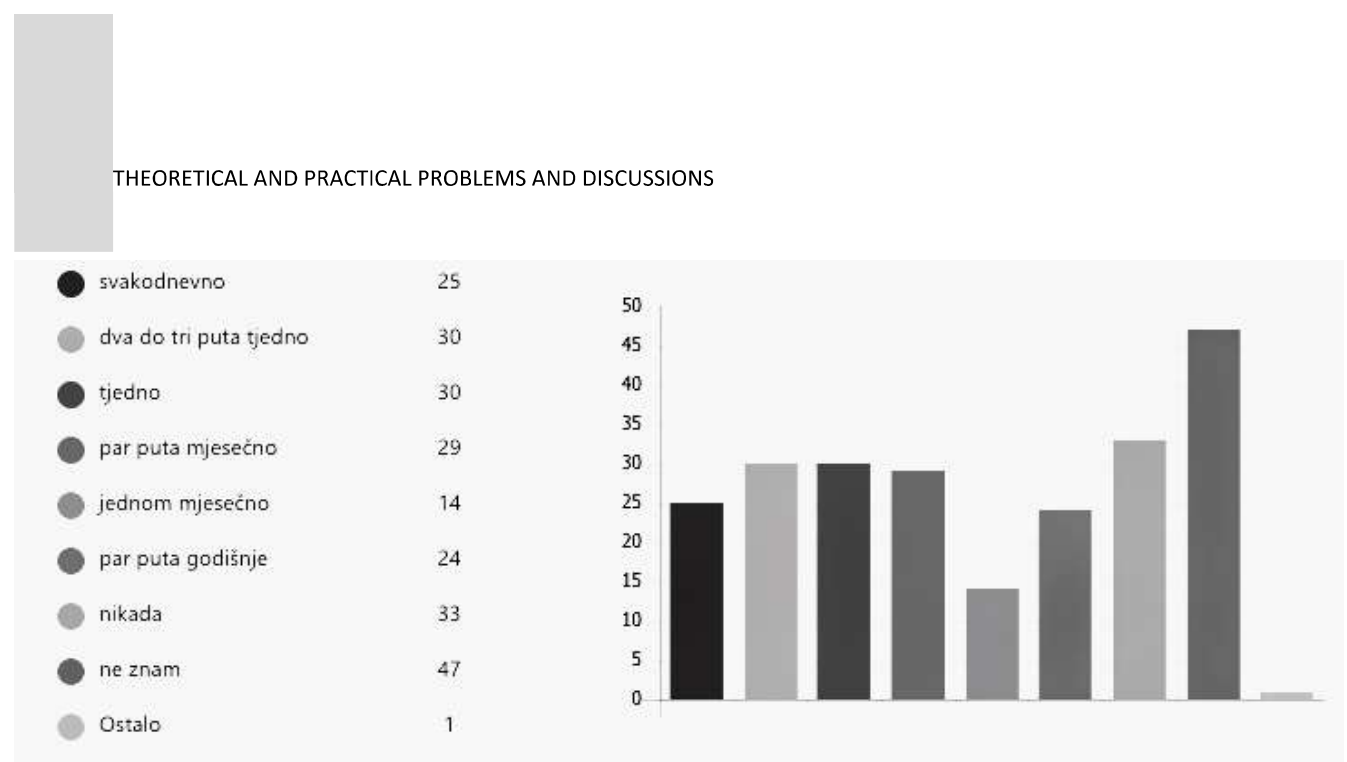

Figure 9. Received content on social networks

Most of the surveyed students do not remember when they received content from the teachers for the first time, that was useful for teaching - 54.62\% (N-134). A year ago $14.53 \%$ $(\mathrm{N}-33)$ of students received such content, two years ago $4.84 \%(\mathrm{~N}-11)$, between two and five years ago $12.77 \%(\mathrm{~N}-29)$, more than five years ago $2.64 \%(\mathrm{~N}-6)$. The answer "Other" was selected by $6.16 \%(\mathrm{~N}-14)$ students.

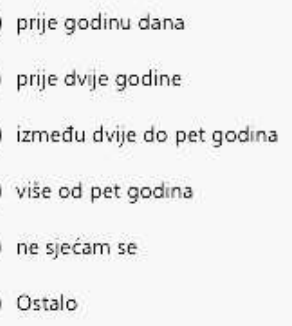

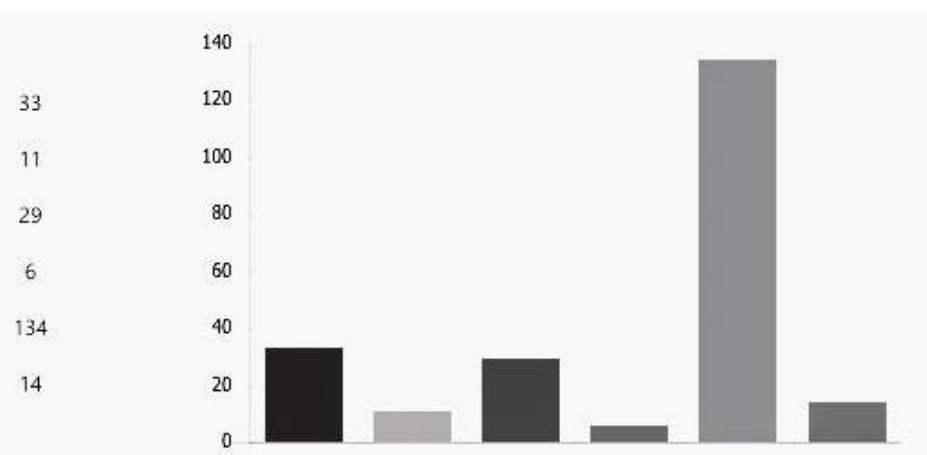

Figure 10. Received teaching content on social networks

\section{Discussion}

\section{Social networks}

Social networks are an integral part of our social life because we use them to communicate with each other, for arranging meetings, sharing texts, photos, documents, links, videos and other similar media content (Kušić, 2010). In addition to the term "social networks", the term "social networking" also appears in public discourse. These two terms are often used as synonyms, although there are differences (Kušić, 2010, 104).

The first forms of social networks emerged in the nineties. They culminate in popularity with Facebook. Very soon after the popular Facebook, other social networks appeared, which significantly influenced the "hyperconnection of man" (Christakis and Fowler, 2010: 258), i.e. better and faster sharing of information with a large number of virtual or real friends. In this way, humans became "Homo dictyousa or networked man" (Christakis and Fowler, 2010: 275). 
Alta Pavin Banović, Sanja Dravinski SOCIAL NETWORKS FOR BETTER EDUCATION AND BETTER..

\section{Social networks in the educational process}

The purpose and goal of the teaching process is to achieve successful and excellent results. The process is influenced by parents as the first educators of their children and teachers. Education makes a significant impact on the development of a person and personality because it educates for autonomy and independence. During schooling, the student lays the foundations of his or her life roles and when "he or she must learn to be both individual and social" (Aronson, Wilson and Akert, 2005: 130). It is the task of students, during formal education, to master knowledge and learn skills, develop positive attitudes towards work and engage in positive interactions with both peers and adults (Aronson et al., 2005). "By participating in the 'herd', young people seek to be similar to their peers, their interests and values, which will affect their position in the smaller groups to which they belong, otherwise they will be excluded" (Aronson et al., 2005: 148). Belonging to a group is no longer determined by the same clothing style but by participating in the same social networks and using the same language because in this way they gain recognition and respect. In order to give social networks a positive connotation that would be acceptable to participants in the educational process, social networks could be used to share information and ready-made teaching content between students and between teachers and students.

The goal of the participants in the educational process is to successfully implement the planned teaching curricula and teach students to learn and to use relevant sources of information to solve teaching tasks. It is necessary to educate students for the media and, today, especially the digital media of information and communication technologies, which have become the life habitus of both today's millennial generation and the Baby Boomer generation. Today's forms of online communication are simpler and faster compared to the forms of communication used until the end of the 20th century. These new forms of social communication have a positive and a negative role in the life of every student, teacher and finally every person and we can actively use them for personal psychological, social, cultural, spiritual development and progress in the teaching process. Parents, educators, teachers are obliged to educate their children and students for the media and critical reflection on the use of the content offered in the media (Mandarić, 2012). "In the education of children and young people, a constructive and quality relationship between the creators of media content and educational institutions is important. Only through an educational alliance of creators of media programs and educational structures can a space be created for joint educational activities" (Mandarić, 2012: 144).

\section{Reform of the teaching process}

The implementation of the teaching process in Croatian education is currently going through its evolution. The modern approach to learning and teaching puts emphasis on research and guided learning, wants to teach students how to learn, use digital tools and information and communication technologies. Significant changes occur in the teacher-student relationship where the student is at the center as an active subject who learns independently. "An attempt is made to make a step forward from a 'teaching society' to a 'learning society" (Rodek, 2011: 15). Gerhard Zimmer (1996) recalls that in 398 St. Augustine emphasized that it is not teaching that is important but learning, that is, one can successfully be taught only by one's own "internal teaching" (Rodek, 2011: 12), which we rediscovered in the school system in the 21th century.

The reform of the School for Life, which is increasingly penetrating the school system, poses, due to the formation of an appropriate learning environment, new didactic challenges to teachers. Teachers' competencies need to be improved, supplemented with new methodological and communication competencies in order to conduct quality pedagogical work. It is necessary to emphasize the "possibilities of networking over the Internet" and to try to connect 
the existing forms and methods with the teaching media (Rodek, 2011: 20). The use of digital media facilitates and improves the quality and quantity of learning and its positive results because the student can independently decide what to learn, when to learn, can determine the pace of learning which increases personal responsibility for learning (Rodek, 2011: 21). The use of new media enables the publication and sharing of teaching materials and, in communication with other participants in the teaching process, their training to more successful presentation (Rodek, 2011: 22). "Considering the possibilities of sharing information in education through the media, Karimi (2006) mentions that multimedia aids have always been a strong component of the curriculum for many school subjects and advocates the educational usefulness of various online collaboration tools because they encourage productive student participation and benefit both the teachers and the students" (Sakal, Matković and Tumbas, 2012: 765). Also, "social networks provide a more individual approach to the student that gives positive and good results because the student can immediately get feedback from the teacher. Students are encouraged to work independently, to research, be creative, do practical work, make individual arrangements for examination and evaluation of their achievements" (Bilić, Zloković, 2004: 113).

The results of the survey from the Medical School Osijek can be compared, at least in part, with the article Readiness for adoption and application of web 2.0 technologies in secondary education - the case of Vojvodina by M. Sakal, P. Matković and P. Tumbas published in Croatian Journal of Education, 2012. This article describes the research conducted on online content that the teacher has created and online learning through social networking and sharing of digital multimedia content. It discusses the possibility for teachers to publish materials such as additional texts for clarification of the teaching materials, useful links, multimedia content and online tests. This research briefly concludes that the introduction of information and communication technologies in the educational process is inevitable because the Web 2.0 technology is recognized as a serious help to teachers in monitoring students and to students in their adoption of educational content (Sakal, Matković and Tumbas, 2012).

\section{Conclusion}

The aim of this research is to emphasize the preventive and positive importance of using social networks in the educational process. Social networks offer an increasing array of useful tools that can be used for quality communication and exchange of digital teaching material. Discussing this subject Rodek (2011) has placed emphasis on network 2.0 technology that brings us new opportunities for collaboration, content exchange, blogs and virtual social networks. The task of the participants involved in the educational teaching process is to encourage online learning as a networked learning: education, upbringing, playing games, communication, socialization and cooperation.

Schools in the 21st century reflect on the human orientation as support for the development of positive relationships between the participants of the educational process.

Modern information and communication technologies media offer better communication of individuals because they connect people and thus enable faster flow of information.

Today's information and communication technologies, which we are becoming more aware of every day and which encourage us to develop competencies and literacy in the 21st century, in addition to traditional teaching methods, occupy an important place in education. 


\section{REFERENCES}

Anić, V. (1991). Rječnik hrvatskoga jezika. Zagreb: Novi Liber.

Anić, V. (2003). Veliki rječnik hrvatskoga jezika. Zagreb: Novi Liber.

Anić, V., \& Goldstein, I. (2000). Rječnik stranih riječi. Zagreb: Novi Liber.

Aronson, E., Wilson, T. D., \& Akert, R. M. (2005). Socijalna psihologija. Zagreb: MATE.

Bilić, V., \& Zloković, J. (2004). Fenomen maltretiranja djece. Zagreb: Naklada Ljevak.

Blažević, D., Cividini-Stranić, E., \& Beck-Dvoržak, M. (1978). Medicinska psihologija. Zagreb: JUMENA.

Christakis, N. A., \& Fowler, J. H. (2010). Povezani. Zagreb: Algoritam.

Kušić, S. (2010). Online društvene mreže i društveno umrežavanje kod učenika osnovne škole: navike facebook generacije. Život i škola, 56(2), 103-125.

Mandarić, V. (2012). Novi mediji i rizični ponašanje djece i mladih. Bogoslovska smotra, 82(1), 131149.

Rodek, S. (2011). Novi mediji i nova kultura učenja. Napredak, 152(1), 9-28.

Sakal, M., Matković, P., \& Tumbas, P. (2012). Spremnost na usvajanje i primjenu tehnologija web 2.0. u srednjem obrazovanju - slučaj Vojvodine. Croatian Journal of Education, 14(4), 743-770. 